\title{
Peak Expiratory Flow Rate of Jute Mill Workers in Calcutta
}

\author{
B. P. Chattopadhyay, SK. Jane Alam, S. Thakur \\ and P. K. GANGOPADHYAY \\ Regional Occupational Health Centre (Eastern). \\ Calcutta-700 016, India
}

Abstract: Ventilatory capacity of 32 control and 318 asymptomatic male jute mill workers of the Calcutta area, India was measured by Wright's Peak Flowmeter. Mean values of peak expiratory flow rate (PEFR) was $514 \pm$ $66.41 \ell / \mathrm{min}$ in Control and $475 \pm 66.02 \ell / \mathrm{min}$ and $462 \pm 67.42 \ell / \mathrm{min}$ in exposed non-smoker and smoker workers respectively. The relationship of PEFR with age, height, duration of exposure and smoking habit were studied. Multiple regression techniques were used to determine the form of the relationship of age, height, exposure and smoking habit with PEFR. The findings have been compared with those of Indian and foreign authors. The possible reasons of difference includes smoking habit, occupational exposure, physical background and residence in polluted area etc.

Key words: ventilatory capacity, peak expiratory flow rate, asymptomatic, regression, occupational exposure.

(Received 25 March 1994, accepted 24 August 1994)

\section{Introduction}

The Wright's Peak Flowmeter is a device for measuring peak expiratory flow rate (PEFR) introduced by Wright and Mckerrow in 1959 [1] for assessing ventilatory capacity. It has been used widely because of its accuracy and reproducibility. The apparatus is small and easy to manage, and it does not require any electric power to operate. Measurement of peak expiratory flow rate is specially suited for use not only at the bed side of the patient but in epidemiological surveys. It has also been used by clinicians in out-patient departments, chest clinics and in general practice. The PEFR has received general acceptance as a useful test of ventilatory capacity [2]. A number of studies [3, 4] have already shown the usefulness of this parameter (PEFR) for rapid determination of the pulmonary function or in evaluating changes in patients' degree of pulmonary disability. Compared with other instruments 
which measure ventilatory capacity, the Wright's Peak Flowmeter has these above qualities and the speed with which the test is performed except a problem in effort dependent for subjects. Evaluation of PEFR requires knowledge of its range in normal subjects of the same sex, age and occupation. However, there is still uncertainty among scientists regarding the normal values of PEFR. The present study was undertaken to report the PEFR of 32 control subjects not exposed to the jute mill and 318 asymptomatic jute mill workers within the age range of $21-55$ years and 21 - 60 years respectively. Regression equations have been calculated for the purpose of predicting the values of PEFR of different populations. Possible reasons are discussed for the differences between our findings and those of other authors.

\section{Materials and Methods}

The subjects of the present study were asymptomatic healthy male jute mill workers. Data were available on 32 control subjects taken from the office staff, securities and maintenance staff of the same jute mill, and of the same socioecomamic status, having no respiratory complaint and smoking history, and 318 asymptomatic jute mill workers. Measurements of PEFR were made on two standard model Wright's Peak Flowmeter and the same technician completed the whole experiment. These instruments were calibrated by the manufacturer and checked every day by measuring our own PEFR before starting the experiment. It was measured in standing position with a nose clip. Among these workers all control subjects were non-smokers and among the jute mill workers 166 workers were non-smokers and 152 smokers all current smokers. The purpose and technique of the test was explained to every subject and this was followed by a demonstration of its performance. After two to three trials the subject was exhorted to make a maximal effort and was closely watched to ensure that the person maintained an airtight seal between the lips and the mouthpiece of the instrument. The highest value of PEFR achieved in three to five successive attempts were recorded and taken for calculation. A disposable mouthpiece was used for each subject. Standing height was measured on a standard scale after the removal of shoes. The age was recorded by asking and according to the joining registar of the mill. Smoking and occupational history of the workers were recorded by a questionnaire method to the extent that it was practicable. All control subjects were non-smokers and had no history of respiratory disease during childhood and are free of any other respiratory diseases at present. In the case of the jute mill workers only asymptomatic workers were taken for the study. 


\section{Results}

Table 1 represents the physical chracteristics and peak expiratory flow rate of the control and asymptomatic jute mill workers. PEFR values of the control subjects were compared with exposed non-smokers, smokers and the

Table 1. Physical measurement and peak expiratory flow rate of control and exposed workers (Mean $\pm \mathrm{SD}$ )

\begin{tabular}{llcccc}
\hline & $\begin{array}{c}\text { Smoking } \\
\text { habit }\end{array}$ & $\begin{array}{c}\text { Age } \\
(\mathrm{yrs})\end{array}$ & $\begin{array}{c}\text { Height } \\
(\mathrm{cm})\end{array}$ & $\begin{array}{c}\text { PEFR } \\
(\ell / \mathrm{min})\end{array}$ & $\begin{array}{c}\text { PEFR }(\ell / \mathrm{min}) \text { of the } \\
\text { entire series }\end{array}$ \\
\hline $\begin{array}{llc}\text { Control } \\
\mathrm{N}=32\end{array}$ & $\mathrm{NS}$ & 39 & 167 & 514 & 514 \\
& $\mathrm{~N}=32$ & \pm 9.05 & \pm 6.22 & \pm 66.41 & \pm 66.41 \\
& $\mathrm{NS}$ & 40 & 165 & 475 & \\
Exposed & $\mathrm{N}=166$ & \pm 9.93 & \pm 6.20 & \pm 66.07 & 469 \\
$\mathrm{~N}=318$ & $\mathrm{~S}$ & 42 & 165 & 462 & \pm 66.41 \\
& $\mathrm{~N}=152$ & \pm 8.10 & \pm 5.70 & \pm 67.42 & \\
\hline
\end{tabular}

$\mathrm{NS}=$ Non-smoker; $\mathrm{S}=$ Smoker

Table 2. PEFR $(\ell / \mathrm{min})$ of the jute mill workers according to duration of exposure (Mean $\pm \mathrm{SD})$

\begin{tabular}{|c|c|c|c|c|c|c|c|c|}
\hline $\begin{array}{c}\text { Exposure } \\
\text { (yrs) }\end{array}$ & $\begin{array}{c}\text { Smoking } \\
\text { habit }\end{array}$ & Batching & Spinning & Weaving & Winding & Beaming & Finishing & General \\
\hline \multirow{3}{*}{ Up to 10} & NS & $\begin{array}{l}580 \\
\pm 63.63 \\
(2)\end{array}$ & $\begin{array}{l}493 \\
\pm 52.51 \\
(6)\end{array}$ & $\begin{array}{l}463 \\
\pm 74.30 \\
(8)\end{array}$ & $\begin{array}{l}470 \\
\pm 56.56 \\
(2)\end{array}$ & $\begin{array}{l}565 \\
\pm 35.35 \\
(2)\end{array}$ & $\begin{array}{l}400 \\
\pm 9.00 \\
(1)\end{array}$ & $\begin{array}{l}523 \\
\pm 46.45 \\
(3)\end{array}$ \\
\hline & $\mathrm{S}$ & $\begin{array}{l}523 \\
\pm 24.74 \\
(2)\end{array}$ & $\begin{array}{l}553 \\
\pm 116.67 \\
(2)\end{array}$ & $\begin{array}{l}515 \\
\pm 0.00 \\
(1)\end{array}$ & $\begin{array}{l}453 \\
\pm 45.96 \\
(2)\end{array}$ & $\begin{array}{l}500 \\
\pm 42.42 \\
(2)\end{array}$ & $\begin{array}{l}000 \\
\pm 0.00 \\
-\end{array}$ & $\begin{array}{l}483 \\
\pm 38.89 \\
(2)\end{array}$ \\
\hline & NS & $\begin{array}{l}439 \\
\pm 61.38 \\
(19)\end{array}$ & $\begin{array}{l}490 \\
\pm 52.98 \\
(6)\end{array}$ & $\begin{array}{l}493 \\
\pm 60.58 \\
(22)\end{array}$ & $\begin{array}{l}498 \\
\pm 58.15 \\
(5)\end{array}$ & $\begin{array}{l}532 \\
\pm 52.04 \\
(3)\end{array}$ & $\begin{array}{l}486 \\
\pm 62.72 \\
(13)\end{array}$ & $\begin{array}{l}483 \\
\pm 72.50 \\
(6)\end{array}$ \\
\hline \multirow[t]{2}{*}{$11-20$} & $\mathrm{~S}$ & $\begin{array}{l}470 \\
\pm 27.38 \\
(5)\end{array}$ & $\begin{array}{l}454 \\
\pm 77.31 \\
(9)\end{array}$ & $\begin{array}{l}480 \\
\pm 75.60 \\
(16)\end{array}$ & $\begin{array}{l}513 \\
\pm 50.17 \\
(6)\end{array}$ & $\begin{array}{l}467 \\
\pm 43.38 \\
(5)\end{array}$ & $\begin{array}{l}484 \\
\pm 73.68 \\
(5)\end{array}$ & $\begin{array}{l}523 \\
\pm 32.51 \\
(5)\end{array}$ \\
\hline & NS & $\begin{array}{l}434 \\
\pm 60.11 \\
(7)\end{array}$ & $\begin{array}{l}464 \\
\pm 58.45 \\
(8)\end{array}$ & $\begin{array}{l}474 \\
\pm 68.75 \\
(17)\end{array}$ & $\begin{array}{l}433 \\
\pm 53.46 \\
(3)\end{array}$ & $\begin{array}{l}432 \\
\pm 144.95 \\
(2)\end{array}$ & $\begin{array}{l}432 \\
\pm 60.70 \\
(8)\end{array}$ & $\begin{array}{l}488 \\
\pm 40.97 \\
(10)\end{array}$ \\
\hline \multirow[t]{2}{*}{$21-30$} & $\mathrm{~S}$ & $\begin{array}{l}431 \\
\pm 47.24 \\
(14)\end{array}$ & $\begin{array}{l}455 \\
\pm 39.62 \\
(12)\end{array}$ & $\begin{array}{l}466 \\
\pm 74.34 \\
(15)\end{array}$ & $\begin{array}{l}448 \\
\pm 65.11 \\
(10)\end{array}$ & $\begin{array}{l}424 \\
\pm 44.60 \\
(4)\end{array}$ & $\begin{array}{l}438 \\
\pm 60.12 \\
(7)\end{array}$ & $\begin{array}{l}489 \\
\pm 57.78 \\
(11)\end{array}$ \\
\hline & NS & $\begin{array}{l}400 \\
\pm 0.00 \\
(1)\end{array}$ & $\begin{array}{l}410 \\
\pm 0.00 \\
(1)\end{array}$ & $\begin{array}{l}449 \\
\pm 72.67 \\
(7)\end{array}$ & $\begin{array}{l}460 \\
\pm 0.00 \\
(1)\end{array}$ & $\begin{array}{l}533 \\
\pm 10.60 \\
(2)\end{array}$ & $\begin{array}{l}475 \\
\pm 7.07 \\
(2)\end{array}$ & $\begin{array}{l}320 \\
\pm 0.00 \\
(1)\end{array}$ \\
\hline $31 \&$ above & $\mathrm{S}$ & $\begin{array}{l}465 \\
\pm 35.35 \\
(2)\end{array}$ & $\begin{array}{l}340 \\
\pm 0.00 \\
(1)\end{array}$ & $\begin{array}{l}449 \\
\pm 84.73 \\
(5)\end{array}$ & $\begin{array}{l}415 \\
\pm 70.71 \\
(2)\end{array}$ & $\begin{array}{l}300 \\
\pm 0.00 \\
(1)\end{array}$ & $\begin{array}{l}355 \\
\pm 55.67 \\
(5)\end{array}$ & $\begin{array}{l}000 \\
\pm 0.00 \\
-\end{array}$ \\
\hline
\end{tabular}

NS $=$ Non-smoker; $\mathrm{S}=$ Smoker

Figures within the parenthesis indicate the number of subjects. 
workers of the entire series showed highly significant differences $(P<0.01, P<$ 0.001 and $P<0.001)$. But the difference between exposed non-smokers and smoker workers are statistically non-significant.

Table 2 depicts the PEFR values of the non-smoker and smoker jute mill workers of different departments according to their duration of exposure. In most of the departments exposed non-smoker workers had higher PEFR values than the smokers, but the differences were statistically non-significant. In weaving, spinning and winding, the smoker workers had higher values than the non-smokers. The distribution of workers of some departments was very much less and disimilar. Changes of PEFR according to smoking habit among different groups of jute mill workers are presented in Table 3. In

Table 3. PEFR $(\ell / \mathrm{min})$ of jute mill workers according to smoking habit (Mean $\pm \mathrm{SD}$ )

\begin{tabular}{|c|c|c|c|c|c|c|}
\hline Process & $\begin{array}{c}\text { Smoking } \\
\text { habit }\end{array}$ & $\begin{array}{c}\text { No. of } \\
\text { subject }\end{array}$ & $\begin{array}{l}\text { Age } \\
\text { (yrs) }\end{array}$ & $\begin{array}{l}\text { Height } \\
(\mathrm{cm})\end{array}$ & $\begin{array}{c}\text { PEFR } \\
(\ell / \text { min })\end{array}$ & $\begin{array}{l}\text { Entire series } \\
(\ell / \mathrm{min})\end{array}$ \\
\hline $\begin{array}{l}\text { Control } \\
\mathrm{N}=32\end{array}$ & NS & 32 & $\begin{array}{l}39 \\
\pm 9.05\end{array}$ & $\begin{array}{l}167 \\
\pm 6.22\end{array}$ & $\begin{array}{l}514 \\
\pm 66.40\end{array}$ & $\begin{array}{l}514 \\
\pm 66.40\end{array}$ \\
\hline \multirow{2}{*}{$\begin{array}{l}\text { Batching } \\
N=47\end{array}$} & NS & 24 & $\begin{array}{l}41 \\
\pm 9.19\end{array}$ & $\begin{array}{l}163 \\
\pm 5.30\end{array}$ & $\begin{array}{l}448 \\
\pm 70.52\end{array}$ & $\begin{array}{l}449 \\
\pm 59.54\end{array}$ \\
\hline & $\mathrm{S}$ & 23 & $\begin{array}{l}45 \\
\pm 7.16\end{array}$ & $\begin{array}{l}164 \\
\pm 5.97\end{array}$ & $\begin{array}{l}451 \\
\pm 48.46\end{array}$ & \\
\hline \multirow{2}{*}{$\begin{array}{l}\text { Spinning } \\
\mathrm{N}=47\end{array}$} & NS & 23 & $\begin{array}{l}35 \\
\pm 10.27\end{array}$ & $\begin{array}{l}163 \\
\pm 6.81\end{array}$ & $\begin{array}{l}478 \\
\pm 54.72\end{array}$ & $\begin{array}{l}468 \\
\pm 63.00\end{array}$ \\
\hline & $\mathrm{S}$ & 24 & $\begin{array}{l}39 \\
\pm 8.88\end{array}$ & $\begin{array}{l}163 \\
\pm 5.75\end{array}$ & $\begin{array}{l}458 \\
\pm 69.37\end{array}$ & \\
\hline \multirow{2}{*}{$\begin{array}{l}\text { Weaving } \\
\mathrm{N}=91\end{array}$} & NS & 54 & $\begin{array}{l}40 \\
\pm 10.57\end{array}$ & $\begin{array}{l}166 \\
\pm 5.90\end{array}$ & $\begin{array}{l}477 \\
\pm 66.75\end{array}$ & $\begin{array}{l}475 \\
\pm 69.43\end{array}$ \\
\hline & $\mathrm{S}$ & 37 & $\begin{array}{l}42 \\
\pm 6.88\end{array}$ & $\begin{array}{l}166 \\
\pm 6.05\end{array}$ & $\begin{array}{l}471 \\
\pm 74.12\end{array}$ & \\
\hline \multirow{2}{*}{$\begin{array}{l}\text { Winding } \\
N=31\end{array}$} & NS & 11 & $\begin{array}{l}39 \\
\pm 10.63\end{array}$ & $\begin{array}{l}165 \\
\pm 8.68\end{array}$ & $\begin{array}{l}472 \\
\pm 55.19\end{array}$ & $\begin{array}{l}467 \\
\pm 60.05\end{array}$ \\
\hline & $\mathrm{S}$ & 20 & $\begin{array}{l}41 \\
\pm 8.66\end{array}$ & $\begin{array}{l}165 \\
\pm 4.59\end{array}$ & $\begin{array}{l}464 \\
\pm 64.79\end{array}$ & \\
\hline \multirow{2}{*}{$\begin{array}{l}\text { Beaming } \\
\mathrm{N}=21\end{array}$} & NS & 9 & $\begin{array}{l}42 \\
\pm 11.83\end{array}$ & $\begin{array}{l}167 \\
\pm 4.27\end{array}$ & $\begin{array}{l}526 \\
\pm 67.76\end{array}$ & $\begin{array}{l}479 \\
\pm 65.55\end{array}$ \\
\hline & $\mathrm{S}$ & 12 & $\begin{array}{l}39 \\
\pm 8.72\end{array}$ & $\begin{array}{l}165 \\
\pm 5.24\end{array}$ & $\begin{array}{l}444 \\
\pm 65.08\end{array}$ & \\
\hline \multirow{2}{*}{$\begin{array}{l}\text { Finishing } \\
N=41\end{array}$} & NS & 24 & $\begin{array}{l}41 \\
\pm 7.85\end{array}$ & $\begin{array}{l}163 \\
\pm 4.79\end{array}$ & $\begin{array}{l}464 \\
\pm 63.25\end{array}$ & $\begin{array}{l}449 \\
\pm 71.54\end{array}$ \\
\hline & $\mathrm{S}$ & 17 & $\begin{array}{l}46 \\
\pm 7.35\end{array}$ & $\begin{array}{l}165 \\
\pm 6.24\end{array}$ & $\begin{array}{l}427 \\
\pm 78.58\end{array}$ & \\
\hline \multirow{2}{*}{$\begin{array}{l}\text { General } \\
\mathrm{N}=38\end{array}$} & NS & 20 & $\begin{array}{l}43 \\
\pm 8.60\end{array}$ & $\begin{array}{l}167 \\
\pm 6.80\end{array}$ & $\begin{array}{l}483 \\
\pm 63.81\end{array}$ & $\begin{array}{l}490 \\
\pm 56.54\end{array}$ \\
\hline & $\mathrm{S}$ & 18 & $\begin{array}{l}42 \\
\pm 8.67\end{array}$ & $\begin{array}{l}166 \\
\pm 5.38\end{array}$ & $\begin{array}{l}498 \\
\pm 50.64\end{array}$ & \\
\hline
\end{tabular}

$\mathrm{NS}=$ Non-smoker; $\mathrm{S}=$ Smoker 
Table 4. Level of significance of PEFR of jute mill workers with smoking habit

\begin{tabular}{|c|c|c|c|c|}
\hline & $\begin{array}{c}\text { Control (NS) } \\
\text { Vs } \\
\text { Exposed (NS) }\end{array}$ & $\begin{array}{l}\text { Control (NS)* } \\
\text { Vs } \\
\text { Exposed (S) }\end{array}$ & $\begin{array}{c}\text { Control (NS) } \\
\text { Vs } \\
\text { Exposed }(\mathrm{NS}+\mathrm{S})\end{array}$ & $\begin{array}{c}\text { Exposed }(\mathrm{NS})^{*} \\
\text { Vs } \\
\text { Exposed }(\mathrm{S})\end{array}$ \\
\hline $\begin{array}{c}\text { Batching } \\
\mathrm{N}=47\end{array}$ & $<0.001$ & $<0.001$ & $<0.001$ & NS \\
\hline $\begin{array}{c}\text { Spinning } \\
\mathrm{N}=47\end{array}$ & $<0.05$ & $<0.01$ & $<0.01$ & NS \\
\hline $\begin{array}{c}\text { Weaving } \\
\mathrm{N}=91\end{array}$ & $<0.05$ & $<0.05$ & $<0.01$ & NS \\
\hline $\begin{array}{c}\text { Winding } \\
\mathrm{N}=31\end{array}$ & $<0.05$ & $<0.01$ & $<0.01$ & NS \\
\hline $\begin{array}{c}\text { Beaming } \\
\mathrm{N}=21\end{array}$ & NS & $<0.01$ & NS & $<0.05$ \\
\hline $\begin{array}{c}\text { Finishing } \\
N=41\end{array}$ & $<0.01$ & $<0.001$ & $<0.001$ & NS \\
\hline $\begin{array}{c}\text { General } \\
\mathrm{N}=38\end{array}$ & NS & NS & NS & NS \\
\hline
\end{tabular}

almost all departments the changes between control workers and exposed nonsmokers and smokers and the workers of the whole series showed a significant difference, but the changes in non-smoker and smoker workers of the same exposed group were found statistically non-significant. The level of significance of PEFR among non-smoker and smoker workers of different departments are presented in Table 4.

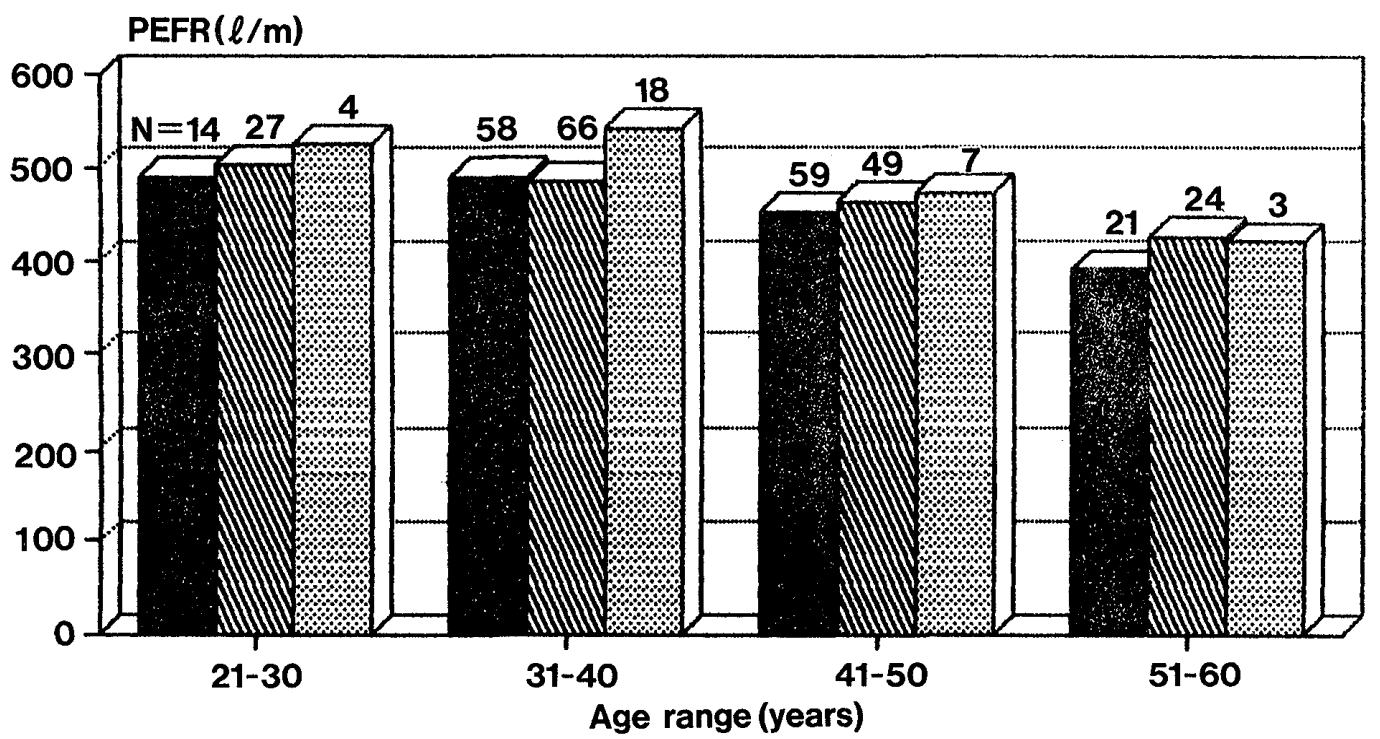

Fig. 1 PEFR $(\ell / \mathrm{min})$ of control subjects and asymptomatic jute mill workers, according to age range.

WORKSM: Smoker jute mill workers.

MIIII WORKNS: Non-smoker jute mill workers.

0. CONTROL: Control subjects. 
Figure 1 represents the values of the control and exposed workers according to different age groups by decade. There were two exposed and one control subject who were below 21 years of age, so they were not considered in the calculation. Among control and exposed workers the PEFR values were reduced as age was increased. Control subjects showed a significant difference $(P<0.05)$ of values when a comparison was made between the age groups of $21-30$ years and $31-40$ years. But a mean difference of values was found in each comparison when the lower and higher age groups were compared. Figure 2 represents the PEFR of control and jute mill workers according to the different height ranges. In these workers the PEFR values were increased as height range was increased. Table 5 represents the regression equations and standard error of estimate (SEE) for control subjects and jute mill workers (non-smokers and smokers) of the age range of $21-55$ years and 21-60 years respectively. Three regression lines have been drawn for these subjects. Figure 3 represents the regression lines of the control and jute mill workers. A multistage step-wise analysis was performed for both types of subjects to determine the form of the regression of PEFR on age, height and exposure. When the data were plotted, it shows that the relation between PEFR and age was curvilinear in control subjects. The powers of age, up to (age) ${ }^{4}$ were included in the regression and the procedure of backward elimination was used to determine the final model.

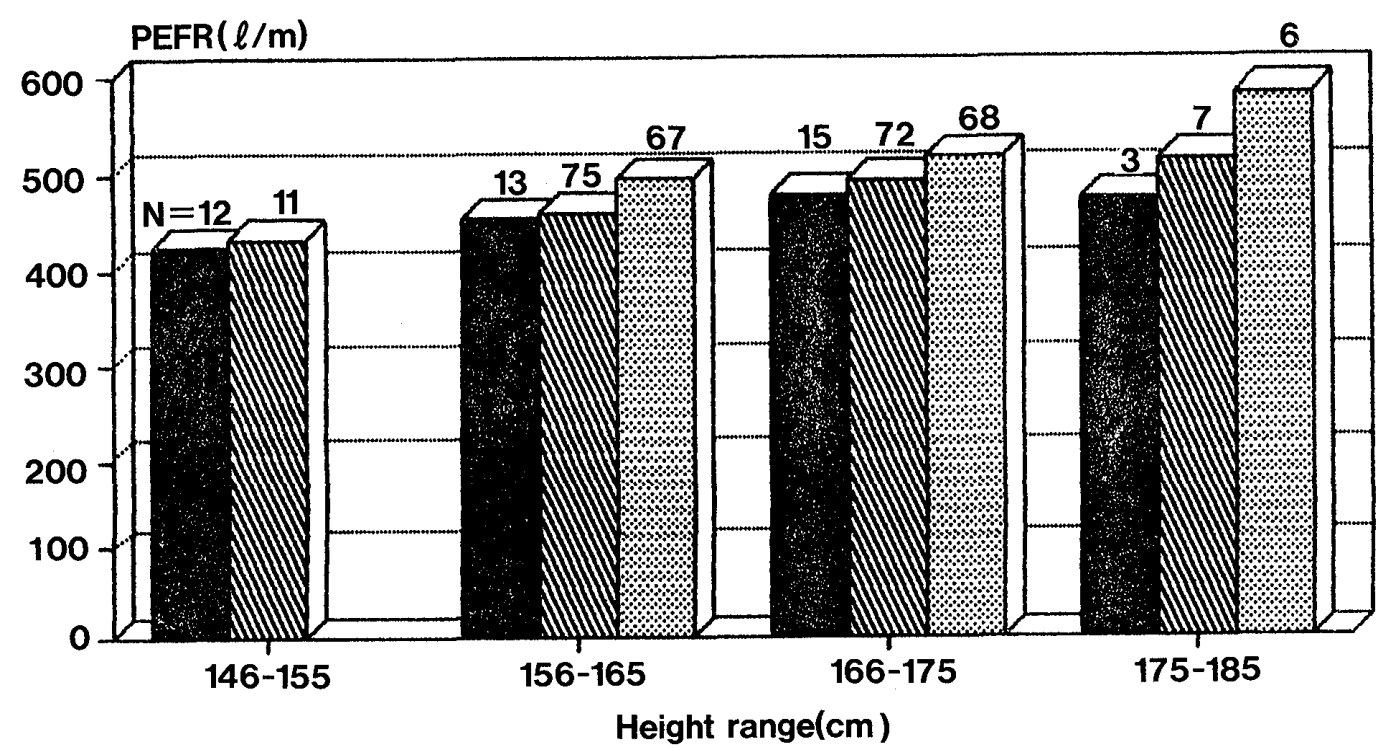

Fig. 2 PEFR $(\ell / \mathrm{min})$ of control subjects and asymptomatic jute mill workers, according to height range.

WORKSM: Smoker jute mill workers.

AlIIII WORKNS: Non-smoker jute mill workers.

CONTROL: Control subjects. 


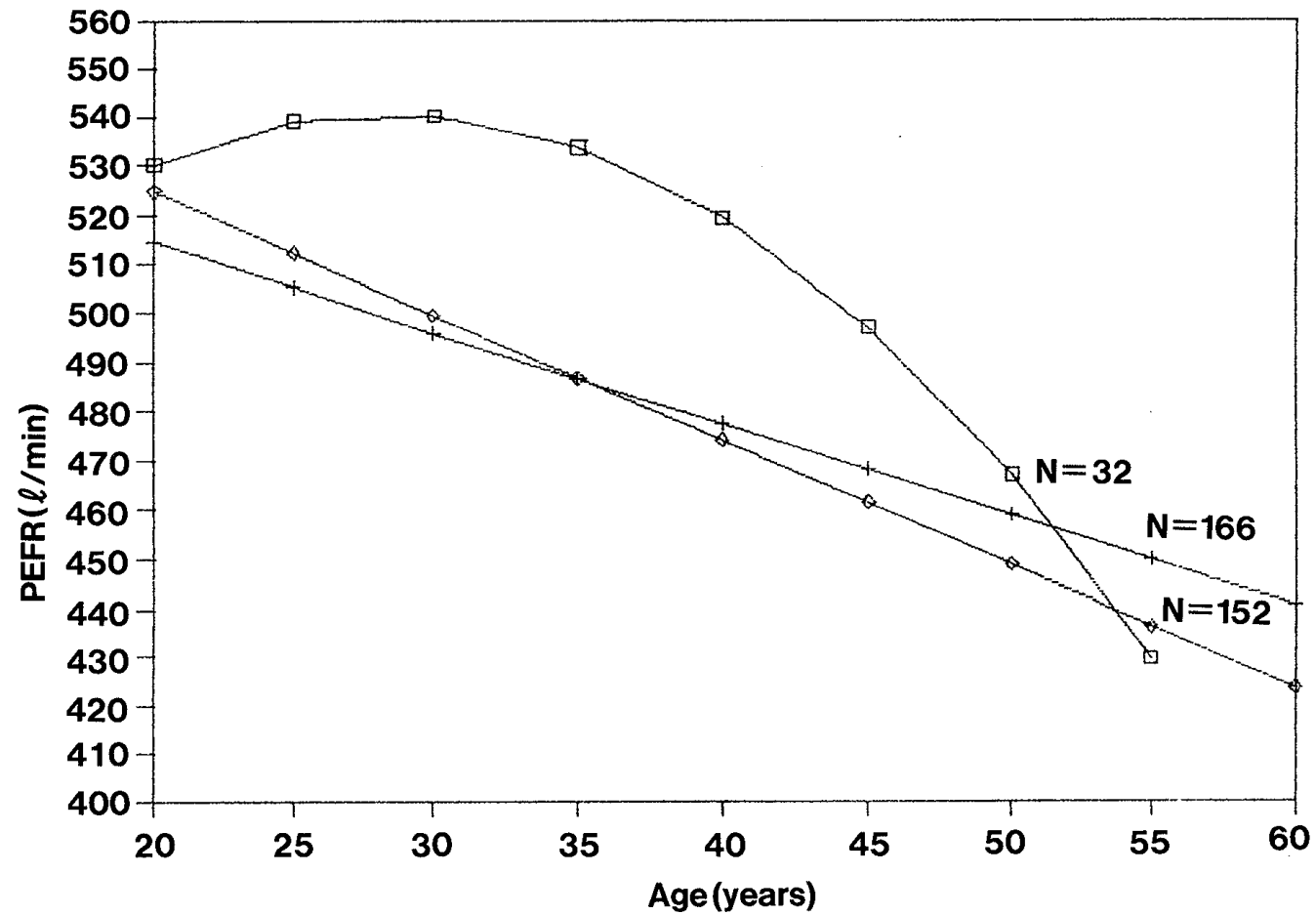

Fig. 3 Regression lines for PEFR $(\ell / \mathrm{min})$ of control subjects and non-smoker and smoker jute mill workers, standardised for age and height.

$\square$ CONTROL: Control subjects.

+ WORKNS: Non-smoker jute mill workers.

$\diamond$ WORKNS: Smoker jute mill workers.

Table 5. Regression, equation of PEFR PEFR $(\ell / \mathrm{min})=\mathrm{b}_{0}+\mathrm{b}_{1}$ age $+\mathrm{b}_{2} \mathrm{age}^{2}+\mathrm{b}_{3}$ height

\begin{tabular}{lccc}
\hline & $\begin{array}{c}\text { Control subject } \\
(21-55 \mathrm{yrs})\end{array}$ & $\begin{array}{c}\text { Jute mill workers } \\
(\text { non smoker }) \\
(21-60 \mathrm{yrs})\end{array}$ & $\begin{array}{c}\text { Jute mill workers } \\
(\text { smokers }) \\
(21-60 \mathrm{yrs})\end{array}$ \\
\hline $\mathrm{b}_{0}$ & -43.3019 & 61.0531 & -15.0551 \\
$\mathrm{~b}_{1}$ & 8.7745 & -1.8491 & -2.5336 \\
$\mathrm{~b}_{2}$ & -0.1553 & - & - \\
$\mathrm{b}_{3}$ & 2.7718 & 2.9539 & 3.5572 \\
$\begin{array}{l}\text { Standard error of } \\
\text { estimate (Std. after }\end{array}$ & 42.97 & 57.03 & 56.71 \\
regression) & & & \\
\hline
\end{tabular}

Their regression lines have been drawn using the standardised height of $166 \mathrm{~cm}$.

All the variables which seem to be related to PEFR were initially included and then eliminated in turn if their additional contribution to the regression sum of squares was not statistically significant. At each stage the variable rejected whose partial co-efficient of determination did not differ significantly from zero. Considering these data of the control subjects, it was found that the three 
Table 6. Comparison of age and height standardised values of PEFR $(\ell / \mathrm{min})$ of control subjects in different studies from India and abroad

\begin{tabular}{|c|c|c|c|}
\hline \multicolumn{2}{|c|}{ Name of authors } & \multirow{2}{*}{$\begin{aligned} \text { Place of study } & \text { Southern India }\end{aligned}$} & \multirow{2}{*}{$\begin{array}{c}\begin{array}{c}\text { Predicted values } \\
(\ell / \mathrm{min})\end{array} \\
516\end{array}$} \\
\hline Kamat et al. & [15] & & \\
\hline Chatterjee et al. & [12] & Eastern India (Non-smoker) & 559 \\
\hline Chatterjee et al. & [12] & Eastern India (Smoker) & 543 \\
\hline Behara et al. & [13] & Orissa Tribal & 556 \\
\hline Malik et al. & [16] & North Indian Adults & 513 \\
\hline Woolcock et al. & {$[17]$} & African coastal & 508 \\
\hline Selby et al. & [11] & Australian & 524 \\
\hline Gregg et al. & [15] & British & 617 \\
\hline Present study & & Eastern Indian (Non-smoker) & 514 \\
\hline
\end{tabular}

Standardized for age 40 years and height $166 \mathrm{~cm}$.

factors age, $(\text { age })^{2}$ and height contributed significantly to the model, whereas the higher power of age beyond (age) ${ }^{2}$ did not significantly improve the model. In non-smoker and smoker jute mill workers the significant factors are age and height but the higher powers of age even $(\text { age })^{2}$ was not a significant factor. Therefore, the relation between PEFR and age in these cases was indicated by a straight line. The duration of exposure to the jute mill made no additional contribution to the regression model that its partial co-efficient of determination was not statistically significant. It accounted for $0.002 \%$ in smokers and $0.001 \%$ in non-smokers of the total variation which age and height had failed to explain for non-smoker and smoker jute mill workers respectively.

Table 6 depicts the age and height standardized values of PEFR of control subjects of different regions of India and abroad.

\section{Discussion}

The regression equations for PEFR on age and height was assumed that there was a linear relation between the fall of PEFR and increasing age [5]. A similar assumption was made by nearly all other authors who have published the normal values of PEFR [6]. A linear fall of PEFR can occur only after the age at which maximal PEFR is attained and if the adolescents are included in the series, the shape of the regression must be curvilinear. Singh and Peri [7], reported that peak flow declines with age, beyond the third decade. According to Gregg and Nunn [5], in both sexes PEFR does not begin to decline until about the age of 35 years. Very similar findings were reported by Brooks and Walter [8]. In the present study similar findings were noted and it was found that the PEFR values declined from the age of the third decade. 
Fairbrain and co-workers [9] reported that the normal persons' mean reading of PEFR was $537 \ell / \mathrm{min}$. The mean blowing was found to decline 0.29 unit for each year increase in age and for each extra inch of height the blow increased by 1.44 units. Weight had no significant effect. In the present study control subjects and jute mill workers had lower PEFR values than their study. Shepard [10] investigated the PEFR values of 72 normal subjects whose PEFR values ranged from $300-700 \ell / \mathrm{min}$. Our observed values are within that limit. Brooks and Walter [8] and Gregg and Nunn [5] reported on PEFR of British subjects, and the report by Selby et al. [11] for Australian subjects showed that PEFR was much higher than that of the present study. The higher PEFR in western subjects appears to be partly due to their larger physical build. Chatterjee et al. [12] reported higher values in Eastern regional peoples in their study, because their subjects belonged to higher socio-economic groups. Behara et al. [13] reported that scheduled tribe (Non-smoker) subjects have higher mean values due to a well built body, physically active habits and living in a pollution free environment.

The jute mill workers showed significantly lower values in different age and height ranges irrespective of smoking habit in comparison to the control subjects. In control subjects of the higher age group $(50-55$ years $)$ the mean values of PEFR were less than the non-smoker and smoker jute mill workers. Only three control workers were present in that age group and their values were lower, which might be due to a less number of subjects and highly personal variation of the parameter (PEFR). But few of the mean differences of values shown between the non-smoker and smoker exposed workers reached a significant level. Rastogi et al. [14] studied the PEFR of industrial male workers, and his predicted values were higher than our observed values of nonsmokers, smokers and mixed workers. Our regression equations for PEFR were obtained by the method of least square deviation. Therefore, powers of age up to (age $)^{2}$ were included in the regression and procedure of backward elimination was used to determine the final model. In control subjects the relation is curvilinear whereas in jute mill workers the significant factor is only age and height, even (age) ${ }^{2}$ is not significant factor that's why the relation of PEFR is a straight line. All the variables were initially included and then eliminated as their additional contribution to the regression sum of squares was not statistically significant. All the probable factors were considered which are significantly correlated with PEFR. Among 19\% of the non-smoker jute mill workers and $22 \%$ of the smoker jute mill worker there were explainable total variation of PEFR values, whereas the same figure for control workers was $52 \%$. This parameter can be widely used on non occupational, occupational subjects and patients to evaluate the ventilatory capacity. The developed 
regression equations for PEFR will be very helpful to predict the parameter of control subjects and asymptomatic jute mill workers in clinical practice and field study.

\section{Acknowledgment}

The authors are grateful to the Director, National Institute of Occupational Health, C. Ahmedabad for his kind permission and encouragement in conducting this study. The authors also thankfully acknowledge the useful suggestions made by Dr. H. N. Saiyed, Officer-in-Charge, ROHC (E). Our thanks are due to Miss M. Haldar and Mr. A. K. Dey for their secretarial assistance.

\section{References}

1. Wright B M \& Mckerrow C B. (1959): Maximum forced expiratory flow rate as a measure of ventilatory capacity. (With a description of a new portable instrument for measuring it). Br Med J 21: 1041-1047

2. Williams M H Jr. \& Kane C (1975): Dose response of patients with asthma inhaled isoproterenol. Am Rev Respir Dis 113: 321-324

3. Flint F J \& Khan M O (1962): Clinical use of peak flowmeter. Br Med J 2: 1231-1233

4. Olsen H C \& Gilson J C (1960): Respiratory symptoms bronchitis and ventilatory capacity in men. Br Med J 1: 1450

5. Gregg I \& Nunn A J (1973): Peak expiratory flow in normal subjects. Br Med J 3: 282-284.

6. Leiner G G, Abbramowitz S, Small M J et al (1963): Expiratory peak flow rate. Am Rev Respir Dis 88: 664-651

7. Singh H D \& Peri Sundaresh (1979): Peak expiratory flow rate in South Indian adults. Ind J Phsiol Pharmac 23: 315-320

8. Brooks A G F \& Walter R E (1972): Peak flow measurements among visitors to a public health exhibition. Thorax 27: 557-562

9. Fairbrain A S, Fletcher C M, Tinker C M et al (1962): A comparison of spirometric and peak flow measurments in men with or without chronic bronchitis. Thorax 17: 168-174

10. Shepard R J (1962): Some observation on peak expiratory flow. Thorax 17: 39-48

11. Selby T \& Read J (1961): Maximum expiratory flow rate in Australian adults. Austr Ann Med 10: 49-53

12. Chatterjee Satipati Nag, Samir Kumar \& Dey Swapan Kumar (1988): Spirometric standards for non-smokers and smokers of India (Eastern Region). Jpn J Physiol 38: 283-298

13. Behera D, Mohanty B K \& Malik S K (1984): Ventilatory capacity of healthy tribals from Orissa state (India). Ind J Med Res 79: 236-238

14. Rastogi S K, Mathur N \& Clerk S H (1983): Ventilatory norms in healthy industrial male workers. Ind J Chest Dis Allied Sci 25: 186-195

15. Kamat S R, Sarma B S, Raju V R K et al (1977): Indian norms for pulmonary function. J Ass Phy India 25: 50-51 
16. Malik S K \& Jindal S K (1985): Normal values of peak expiratory flow rate in healthy north Indian adults-Revision of prediction formula. Ind J Chest Dis Allied Sci 27: 50-51

17. Woolcock A J, Colmer M H \& Blackburn C R B (1972): Factors affecting normal values for ventilatory lung function. Am Rev Res Dis 106: 692-709

カルカッタのインド麻工場における労働者のピークフロー (PEFR)

B. P. チャトパジャイ, S. K. J. アラン, S. サクール, P. K. ガンゴパジャイ 東部地域産業保健センター, カルカッタ, インド

要 旨：インドのカルカッタ地域に拉いて, 32 人の対照群と, 318 人のインド麻工場労働者 (無症状の者)に対して，ライト式ピークフローメーターで換気能力を測定した．対 照群では，ピークフローの平均值は， $514 \pm 66.41 \ell /$ 分であり，労働者の中で非喫煙 者は $475 \pm 66.02 \ell /$ 分, 契煙者は $462 \pm 67.42 \ell /$ 分であった. ピークフローの値と年 令, 身長, 工場での曝露期間, および契煙との関連性を重回帰分析を用いて検討し た，得られた結果を，インドおよび諸外国からの報告と比較すると共に，契煙習慣， 職業性曝露, 身体的背景, あるいは污染地域内での居住, などの要因の及ぼす影響 を考察した.

J UOEH（産業医大誌）16 (4) : 321-331 (1994) 